\title{
Optimization of Bioactive Substances in the Wastes of Some Selective Mediterranean Crops
}

\author{
Ebru Kurtulbaş ${ }^{1}$, Sibel Yazar ${ }^{2}$, Dimitris Makris ${ }^{3}$ (D) and Selin Şahin ${ }^{1, *(\mathbb{D})}$ \\ 1 Department of Chemical Engineering, Engineering Faculty, Istanbul University-Cerrahpaşa, Avcilar, \\ 34320 Istanbul, Turkey \\ 2 Department of Chemistry, Engineering Faculty, Istanbul University-Cerrahpaşa, Avcilar, \\ 34320 Istanbul, Turkey \\ 3 Green Processes \& Biorefinery Group, School of Agricultural Sciences, University of Thessaly, \\ 43100 Karditsa, Greece \\ * Correspondence: selins@istanbul.edu.tr; Tel.: +90-212-4737070 (ext. 17679); Fax: +90-212-4737180
}

Received: 10 April 2019; Accepted: 11 June 2019; Published: 1 July 2019

\begin{abstract}
Production of added products from industrial byproducts is a challenge for the current natural product industry and the extraction field more generally. Therefore, the aim of this study is to valorize the selected Mediterranean crops that can be applied as antioxidants, natural chelating agents, or even as biosolvents or biofuels after special treatment. In this study, the wastes of popular Mediterranean plants were extracted via homogenizer-assisted extraction (HAE) by applying response surface methodology (RSM) to examine the effects of process parameters on the total biophenolic contents (TBCs) of their residues. Box-Behnken design model equations calculated for each system were found significant $(p<0.0001)$ with an adequate value of determination coefficient $\left(R^{2}\right)$. Olive leaf had the highest TBC content (58.62 mg-GAE/g-DW with $0.1 \mathrm{~g}$ sample, $42.5 \%$ ethanol at $6522.2 \mathrm{rpm}$ for $2 \mathrm{~min}$ ), followed by mandarin peel (27.79 $\mathrm{mg}$-GAE/g-DW with $0.1 \mathrm{~g}$ sample, $34.24 \%$ ethanol at $8772 \mathrm{rpm}$ for $1.99 \mathrm{~min}$ ), grapefruit peel (21.12 $\mathrm{mg}-\mathrm{GAE} / \mathrm{g}-\mathrm{DW}$ with $0.1 \mathrm{~g}$ sample, $42.33 \%$ ethanol at $5000 \mathrm{rpm}$ for $1.125 \mathrm{~min}$ ) and lemon peel (16.89 $\mathrm{mg}-\mathrm{GAE} / \mathrm{g}-\mathrm{DW}$ with $0.1 \mathrm{~g}$ sample, 33.62\% ethanol at $5007 \mathrm{rpm}$ for $1.282 \mathrm{~min}$ ). The antioxidant activities of the extracts were measured by several in vitro studies. The most prominent biophenols of the wastes were quantified by high performance liquid chromatography (HPLC). Fourier-transform infrared-attenuated total reflectance (FTIR-ATR) and atomic force microscopy (AFM) techniques were also used for characterization.
\end{abstract}

Keywords: Mediterranean crops; waste; valorization; optimization; FTIR-ATR; AFM

\section{Introduction}

Food waste production covers the whole food life cycle from agricultural and industrial production and processing, to retail and domestic consumptions. In developed countries, $42 \%$ of food waste is produced during domestic consumption, while 39\% is from the food manufacturing industry, $14 \%$ is from the food services sector and $5 \%$ is from the retail and distribution sectors [1]. Nowadays, industrial ecology concepts have been evaluated as a leading principle of eco-innovation that targets the zero waste economy, where waste is used as a raw material for new products and applications. Large quantities of waste generated by food industries cause serious problems both economically and environmentally, as well as resulting in a great loss of high-added value compounds. Moreover, most of these residues have reusable potential in other production systems.

The wastes of fruit and vegetable processes are the most important resources of various types of antioxidants and dietary fibers. The reason for this is that the corresponding byproducts are made from soft tissue that is rich in both components, allowing simultaneous extraction into two separate 
streams [2]. Citrus is the largest fruit crop in the world [3,4], with a global production of approximately 115 million tons per year [5]. Since their water content is less than half the total weight of the fruits, their main byproducts are their peels after processing [6]. The concerned wastes are traditionally evaluated for animal feed, pectin and fuel production [5,7]. Recent studies evaluating these wastes have suggested that some fruit or vegetable byproducts may be natural antioxidant sources. Orange peel has been used for the recovery of phenolic materials, flavonoids, essential oils and carotenoids [5,8,9]. Karsheva et al. obtained extracts from mandarin peels, and examined the level of biophenols in their extract content [6]. Singanusong et al. also found the antioxidant capacity of mandarin peels by various methods, and analyzed their total biophenolic substances [10]. Ateş et al. extracted phenolic antioxidants by various advanced separation methods (microwave-assisted extraction and supercritical- $\mathrm{CO}_{2}$ extraction), using mandarin peel as a raw material [11]. Lemon peel was also used as raw material for pectin and flavonoid production [3,4]. Li et al. extracted lemon peels by enzyme-assisted extraction to get bioactive ingredients [12]. Furthermore, Guimarães et al. compared the water content of the lemon peel in terms of antioxidants, and observed a higher level (about eight times) of phenolic material in lemon peels compared to that of water [13]. Moreover, the same research group compared grapefruit juice and peels with respect to phenolic material. They observed that the peel had an approximately six times higher biophenol level compared to that of grapefruit water. Li et al. recycled grapefruit peels for biologically active materials by means of enzyme-assisted extraction [12].

On the other hand, olive trees are one of the most important fruit trees in Mediterranean countries, covering eight million hectares, which corresponds to about $98 \%$ of the world crop. This output demonstrates the economic and social importance of this crop [14]. Olive leaves, which are byproducts of this crop, also represent $10 \%$ of the total weight of the harvested olives, but this residue remains agricultural waste if it is not assessed [15]. Since olive leaf is a rich source of bioactive substances that have been proven many times to possess health effects, a wide variety of studies have been carried out in this regard [16]. Şahin et al. obtained extract rich in biofenol and flavonoid by using ultrasound-assisted extraction [17]. Xynos et al. [18] and Putnik et al. [19] applied pressurized liquid extraction as an environmentally friendly technology to extract olive leaf for its biophenol substances. Şahin et al. utilized solvent-free microwave extraction to attain olive leaf extract [20]. Mourtzinos et al. [21] and Athanasiadis et al. [22] obtained a rich extract of antioxidants using environmentally friendly and novel solvents, respectively. Khemakhem et al. applied novel separation methods (microfiltration, ultrafiltration and nanofiltration) to acquire extract with a high level of oleuropein (the main ingredient of the olive leaf) [23]. To our knowledge, the number of studies of citrus peels in terms of polyphenol level is quite inadequate, although there have been many studies in which olive leaf has been examined for its natural antioxidants. For this reason, evaluation of these resources, and comparison of the related wastes, is carried out in this study. On the other hand, the concerned waste samples have been extracted with homogenizer-assisted extraction (HAE), which is an extremely simple system with extremely minimal time and investment cost requirements. As the rotary blade spins at a very high speed, the texture is rapidly reduced in size by a combination of excessive shear, cavitation and scissor-like mechanical shear in the narrow gap between the rotor and the stator. Since most rotor stator homogenizers have an open configuration, the product is recirculated repeatedly. Depending on the processing speed and hardness of the tissue sample, the desired results are usually obtained in 15-120 s. The goal of the present study is to optimize the conditions of HAE for obtaining the selected raw materials, depending on their phenolic content, and to identify the richest waste byproduct with respect to bioactive properties.

\section{Materials and Methods}

\subsection{Plant and Chemical Materials}

Olive leaf samples were supplied from Özgün Olive, Olive Oil Co in the Aegean part of Turkey (Ayvalik, Balikesir). Citrus fruits were provided by the Bati Akdeniz Agricultural Research Institute 
(BATEM) in Antalya, Turkey. The samples were dried at ambient conditions. The dried leaves and peels were ground by a grinder (Moulinex Super Blender Grinder, LM209041, Paris, France), and screened through a 22-mesh sieve.

Ethanol (>99.5\%) and methanol (>99.8\%) were from Merck (Darmstadt, Germany), while sodium carbonate, Folin-Ciocalteu, 2,2-diphenyl-1-picrylhydrazyl (DPPH•), 2,9-dimethyl-1,10-phenanthroline (neocuproine), 6-hydroxy-2,5,7,8-tetramethylchroman-2-carboxylic acid (trolox), gallic acid, oleuropein, naringin, formic acid and acetonitrile were from Sigma-Aldrich (St. Louis, MO, USA).

\subsection{Homogenizer-Assisted Extraction}

Residue samples were extracted three times by an ethanol-water solution $(v / v)$ of different concentrations by means of an IKA T25 (ULTRA-TURRAX, Staufen, Germany) brand homogenizer. The homogenization was adjusted to several conditions (Table 1). Before analysis, extracts were filtered through a syringe filter $(0.45 \mu \mathrm{m})$ and kept in dark at $-20{ }^{\circ} \mathrm{C}$.

Table 1. Summary of the HAE-homogenizer-assisted extraction parameters with their units, symbols and levels.

\begin{tabular}{cccccc}
\hline \multirow{2}{*}{ Process Parameters } & \multirow{2}{*}{ Units } & Symbol of the Parameters & \multicolumn{3}{c}{ Levels with the Codes } \\
\cline { 4 - 6 } & & & $-\mathbf{1}$ & $\mathbf{0}$ & $\mathbf{1}$ \\
\hline Solvent Concentration & $\%, v / v$ & $X_{1}$ & 20 & 50 & 80 \\
Solid Mass & $\mathrm{g}$ & $X_{2}$ & 0.1 & 0.175 & 0.25 \\
Extraction time & $\mathrm{min}$ & $X_{3}$ & 0.5 & 1.25 & 2 \\
Speed & $\mathrm{rpm}$ & $X_{4}$ & 5000 & 7000 & 9000 \\
\hline
\end{tabular}

\subsection{Spectrophotometric Analyzes}

Total biophenolic content (TBC) determination of the extracts was carried out spectrophotometrically (PG Instruments, T60/Leicestershire, Leicester, England) depending on the Folin-Ciocalteu method at a wavelength of $765 \mathrm{~nm}$ [24]. The findings were expressed as a gallic acid equivalent on a dried base (mg-GAE/g-DW). Scavenging activity of the ABTS radical was measured following the procedure of Re et al. with slight modifications [25]. The wavelength was selected as $734 \mathrm{~nm}$. Inhibition of ABTS was given as mg trolox equivalent antioxidant activity on a dried base (mg-TEAC/g-DW). Free-radical scavenging activity against the DPPH radical was also achieved by following the report of Yu et al. [26] with some modifications [27]. The wavelength was selected as $517 \mathrm{~nm}$. Inhibition of DPPH was given as mg-TEAC/g-DW. Moreover, cupric ion reducing antioxidant capacity (CUPRAC) assay was applied to measure the antioxidant activity of the residues [28]. Maximum absorbance was observed at $450 \mathrm{~nm}$. The antioxidant activity of the samples was also stated as mg-TEAC/g-DW.

\subsection{Chromatographic Analysis}

Individual phenolic quantification was performed by high-performance liquid chromatography (HPLC). The main ingredients of the selected wastes have been investigated in the literature. After determination of the prominent compounds of the samples, the relevant compounds were provided as standards. Then, standard solutions were prepared in several concentrations to draw a calibration curve. After measuring the absorbance of the samples, the concentrations were determined using the calibration curve. Conditions of HPLC are given in Table 2. 
Table 2. Analyzing conditions of individual phenols along with the gradient program applied.

\begin{tabular}{lccc}
\hline \multicolumn{1}{c}{ HPLC Conditions } & \multicolumn{3}{c}{ Program } \\
\hline Model: Agilent 1260 (Agilent, Waldbronn, Germany) & Time $(\mathrm{min})$ & $\mathrm{A}(\%)$ & $\mathrm{B}(\%)$ \\
Colon: Agilent Eclipse Plus C18 RRHD $18(3 \times 5 \mathrm{~mm} ; 1.8 \mu \mathrm{m})$ & 0.0 & 100 & 0 \\
Mobile phase: A = Water + \% 0.1 formic acid $(v / v)$ & 0.5 & 100 & 0 \\
$\mathrm{~B}=$ Acetonitrile $+\% 0.1$ formic acid $(v / v)$ & 7.0 & 60 & 40 \\
Detection wavelength: $276 \mathrm{~nm}$ & 7.1 & 0 & 100 \\
Flow rate: $1 \mathrm{~mL} / \mathrm{min}$ & 8.6 & 0 & 100 \\
Column temperature: $40^{\circ} \mathrm{C}$ & 8.7 & 100 & 0 \\
Injection volume: $20 \mu \mathrm{L}$ & 10 & 100 & 0 \\
\hline
\end{tabular}

\subsection{Atomic Force Microscopy}

The nanostructural morphologies and height profiles of the lemon peels and olive leaves were examined with an atomic force microscopy (AFM) instrument, which was provided by Nanomagnetics Instruments. It was operated in tapping mode at room temperature using silicon probes coated with the aluminum (PPP-NCLR nanosensors). Samples were scanned before and after extraction processes utilizing a $10 \mu \mathrm{m} / \mathrm{s}$ scanning rate and a $256 \times 256$ pixel resolution. The statistical parameters were evaluated from AFM images using the image analysis software NMI Viewer 2.0.7.

\subsection{Fourier-Transform Infrared-Attenuated Total Reflectance}

The chemical characterization of the extracts was made using a Bruker Alpha-T DRIFT spectrometer with a 528/D model through OPUS 6.5 software (Bruker Optics Inc., Coventry, UK).

\subsection{Statistical Experimental Design}

Box-Behnken design was applied into the selected HAE process as a three-level factorial design for the optimization of four process parameters (Table 1). Since there are relatively many independent variables, Box-Behnken design was selected in order to be more economical in a more effective way [29]. Furthermore, Box-Behnken design, along with response surface methodology (RSM) provides an evaluation of the effects of process parameters and their interactions with the relevant system. In this study, Design-Expert (Stat-Ease, Minneapolis, MN, USA) software version 10.0.4 was used.

The quadratic model of response is described the equation given below:

$$
Y=\beta_{0}+\sum_{\mathrm{i}=1}^{3} \beta_{\mathrm{i}} X_{\mathrm{i}}+\sum_{\mathrm{i}=1}^{3} \beta_{\mathrm{ii}} X_{\mathrm{i}}^{2}+\sum_{\mathrm{i}=1}^{3} \sum_{\mathrm{j}=\mathrm{i}+1}^{3} \beta_{\mathrm{ij}} X_{\mathrm{i}} X_{\mathrm{j}}+\mathrm{e},
$$

where $\beta_{0}$ is the constant, $\beta_{i}$ is the linear and $\beta_{i i}$ is the quadratic (i and $j=4$ ) interaction coefficient. $X_{\mathrm{i}}(\mathrm{i}=1-4)$ is the non-coded factor, while $Y$ represents the dependent parameter, known as the response.

An analysis of variance (ANOVA) test is utilized to assess the model fitting, as well as to determine the interaction between the variables using the same software. A lack of fit test was further applied to the independent and dependent variables for verification of the model fitting.

\subsection{Statistical Analysis}

Analysis of variance (ANOVA) statistical testing was utilized through Tukey's test of InStat software (GraphPad, San Diego, CA, USA) to analyze the means of three replicate outputs.

\section{Results and Discussions}

TBC findings of the olive leaf, grapefruit, lemon and mandarin peel extracts attained by HAE through Box-Behnken design are given in Table 3, which details their EtOH concentration, solid mass, extraction time and speed. 
Table 3. Effects of the independent variables on the TBC-total biophenolic content extraction of the relevant wastes*.

\begin{tabular}{|c|c|c|c|c|c|c|c|}
\hline \multirow{2}{*}{$\begin{array}{c}X_{1} \\
(\% . v / v)\end{array}$} & \multirow{2}{*}{$X_{2}(\mathrm{~g})$} & \multirow{2}{*}{$\begin{array}{c}X_{3} \\
\text { (min) }\end{array}$} & \multirow{2}{*}{$\begin{array}{c}X_{4} \\
(\mathrm{rpm})\end{array}$} & \multicolumn{4}{|c|}{ TBC (mg-GAE/g-DW) } \\
\hline & & & & Olive Leaf & Grapefruit Peel & Lemon Peel & Mandarin Peel \\
\hline 80 & 0.1 & 1.25 & 7000 & $33.06 \pm 0.000$ & $16.06 \pm 0.001$ & $4.23 \pm 0.002$ & $24.06 \pm 0.001$ \\
\hline 20 & 0.175 & 0.5 & 7000 & $34.41 \pm 0.002$ & $12.03 \pm 0.002$ & $6.80 \pm 0.001$ & $20.70 \pm 0.001$ \\
\hline 50 & 0.175 & 0.5 & 5000 & $27.94 \pm 0.001$ & $12.03 \pm 0.001$ & $7.18 \pm 0.001$ & $18.80 \pm 0.001$ \\
\hline 50 & 0.175 & 2 & 9000 & $48.80 \pm 0.000$ & $14.13 \pm 0.001$ & $13.37 \pm 0.002$ & $22.99 \pm 0.000$ \\
\hline 50 & 0.1 & 1.25 & 9000 & $42.56 \pm 0.001$ & $15.06 \pm 0.003$ & $16.23 \pm 0.003$ & $21.90 \pm 0.002$ \\
\hline 80 & 0.175 & 1.25 & 9000 & $33.37 \pm 0.000$ & $10.70 \pm 0.001$ & $14.22 \pm 0.001$ & $17.18 \pm 0.001$ \\
\hline 50 & 0.175 & 1.25 & 7000 & $41.05 \pm 0.000$ & $12.22 \pm 0.002$ & $13.02 \pm 0.001$ & $16.89 \pm 0.001$ \\
\hline 50 & 0.1 & 0.5 & 7000 & $26.06 \pm 0.001$ & $14.06 \pm 0.000$ & $15.23 \pm 0.000$ & $15.56 \pm 0.002$ \\
\hline 50 & 0.175 & 1.25 & 7000 & $40.98 \pm 0.000$ & $13.50 \pm 0.001$ & $13.54 \pm 0.001$ & $15.63 \pm 0.001$ \\
\hline 50 & 0.175 & 1.25 & 7000 & $42.67 \pm 0.000$ & $12.65 \pm 0.001$ & $11.20 \pm 0.001$ & $15.98 \pm 0.002$ \\
\hline 50 & 0.1 & 1.25 & 5000 & $46.90 \pm 0.001$ & $22.40 \pm 0.002$ & $12.40 \pm 0.001$ & $18.90 \pm 0.001$ \\
\hline 50 & 0.1 & 2 & 7000 & $61.25 \pm 0.002$ & $15.06 \pm 0.000$ & $13.23 \pm 0.002$ & $19.73 \pm 0.003$ \\
\hline 50 & 0.25 & 0.5 & 7000 & $30.02 \pm 0.000$ & $9.36 \pm 0.001$ & $7.02 \pm 0.001$ & $1.93 \pm 0.001$ \\
\hline 50 & 0.25 & 1.25 & 5000 & $35.96 \pm 0.001$ & $11.09 \pm 0.002$ & $10.16 \pm 0.001$ & $14.62 \pm 0.001$ \\
\hline 20 & 0.1 & 1.25 & 7000 & $46.73 \pm 0.001$ & $17.06 \pm 0.002$ & $12.23 \pm 0.002$ & $24.23 \pm 0.002$ \\
\hline 20 & 0.175 & 1.25 & 9000 & $43.65 \pm 0.001$ & $12.99 \pm 0.001$ & $10.60 \pm 0.001$ & $17.65 \pm 0.001$ \\
\hline 50 & 0.175 & 1.25 & 7000 & $43.60 \pm 0.001$ & $11.36 \pm 0.001$ & $12.65 \pm 0.002$ & $17.23 \pm 0.002$ \\
\hline 80 & 0.175 & 0.5 & 7000 & $25.27 \pm 0.001$ & $9.56 \pm 0.002$ & $1.46 \pm 0.001$ & $17.18 \pm 0.001$ \\
\hline 50 & 0.175 & 0.5 & 9000 & $35.37 \pm 0.001$ & $8.41 \pm 0.000$ & $7.18 \pm 0.002$ & $25.37 \pm 0.001$ \\
\hline 50 & 0.175 & 1.25 & 7000 & $42.41 \pm 0.001$ & $10.25 \pm 0.001$ & $11.18 \pm 0.000$ & $16.32 \pm 0.001$ \\
\hline 80 & 0.25 & 1.25 & 7000 & $29.09 \pm 0.000$ & $9.62 \pm 0.001$ & $3.69 \pm 0.001$ & $13.69 \pm 0.002$ \\
\hline 20 & 0.175 & 1.25 & 5000 & $35.56 \pm 0.001$ & $13.75 \pm 0.001$ & $8.89 \pm 0.001$ & $20.13 \pm 0.001$ \\
\hline 80 & 0.175 & 2 & 7000 & $36.89 \pm 0.001$ & $9.56 \pm 0.002$ & $2.80 \pm 0.001$ & $17.56 \pm 0.001$ \\
\hline 80 & 0.175 & 1.25 & 5000 & $27.46 \pm 0.002$ & $13.56 \pm 0.001$ & $3.65 \pm 0.002$ & $15.84 \pm 0.000$ \\
\hline 50 & 0.25 & 1.25 & 9000 & $41.09 \pm 0.003$ & $14.29 \pm 0.002$ & $10.56 \pm 0.001$ & $21.62 \pm 0.001$ \\
\hline 20 & 0.175 & 2 & 7000 & $45.37 \pm 0.001$ & $13.37 \pm 0.000$ & $9.75 \pm 0.001$ & $17.75 \pm 0.001$ \\
\hline 20 & 0.25 & 1.25 & 7000 & $38.56 \pm 0.001$ & $12.02 \pm 0.001$ & $10.36 \pm 0.000$ & $7.96 \pm 0.002$ \\
\hline 50 & 0.175 & 2 & 5000 & $44.32 \pm 0.002$ & $13.18 \pm 0.001$ & $10.99 \pm 0.001$ & $25.46 \pm 0.001$ \\
\hline 50 & 0.25 & 2 & 7000 & $45.09 \pm 0.001$ & $11.49 \pm 0.001$ & $10.49 \pm 0.001$ & $20.09 \pm 0.001$ \\
\hline
\end{tabular}

\subsection{Modeling and Optimization by Box-Behnken Design}

Quadratic polynomial models derived for the TBCs extracted from the relevant residues of each crop are given in Table 4. Coefficient of determination $\left(R^{2}\right)$ values also indicate that the equations calculated for the four responses were adequate to explain the relationship between the dependent and independent variables $\left(R^{2}>0.89\right)$.

Table 5 summarizes the statistical results of each extract system. The adequacy of the derived models obtained by Box-Behnken design were verified and found to be significant $(p<0.0001)$ to the experimental findings (Table 3). Regarding olive leaf, time for HAE was the most effective variable of the TBC yield, followed by solvent concentration $(p<0.0001)$. Time effect was also found to be statistically the most significant parameter in the extraction of anthocyanin from red raspberries by Chen et al. [30]. Amount of solid mass was the most significant parameter for the extraction of TBC from grapefruit peel $(p<0.0001)$. Similarly, Jeganathan et al. observed solid mass as an effective parameter for the solvent extraction of polyphenols from red grapes by applying Box-Behnken design [31]. Quadratic power of ethanol concentration was statistically $(p<0.0001)$ the most important parameter of all for the lemon peel extraction by HAE $(p<0.0001)$. Bilgin et al. also reported a second power of ethanol concentration in the HAE of TBC from Sideritis montana L. [32]. Second power of extraction speed was the most influential process parameter affecting the HAE of mandarin peels. This finding is in agreement with that of Şahin et al., where HAE was used for solid-liquid extraction to enrich sunflower oil with polyphenols [33]. 
Table 4. Model equations with coded factors derived by Box-Behnken design through RSM-Response Surface Methodology.

\begin{tabular}{|c|c|c|c|}
\hline \multicolumn{2}{|c|}{ Response } & Equation & $R^{2}$ \\
\hline \multirow{4}{*}{$\begin{array}{c}\text { TBC } \\
(\mathrm{mg}-\mathrm{GAE} / \mathrm{g}-\mathrm{DW})\end{array}$} & Olive leaf & $\begin{array}{l}42.14-4.93 X_{1}-3.06 X_{2}+8.55 X_{3}+2.23 X_{4}+1.05 X_{1} X_{2}+ \\
0.17 X_{1} X_{3}-0.55 X_{1} X_{4}-5.03 X_{2} X_{3}+2.37 X_{2} X_{4}-0.74 X_{3} X_{4} \\
-5.51 X_{1}^{2}+0.36 X_{2}^{2}-1.60 X_{3}^{2}-1.31 X_{4}^{2}\end{array}$ & 0.9233 \\
\hline & Grapefruit peel & $\begin{array}{l}12.00-1.01 X_{1}-2.65 X_{2}+0.94 X_{3}-0.86 X_{4}-0.35 X_{1} X_{2}- \\
0.33 X_{1} X_{3}-0.52 X_{1} X_{4}+0.28 X_{2} X_{3}+2.63 X_{2} X_{4}+1.14 X_{3} X_{4} \\
-0.16 X_{1}^{2}+2.00 X_{2}^{2}-1.17 X_{3}^{2}+1.25 X_{4}^{2}\end{array}$ & 0.9219 \\
\hline & Lemon peel & $\begin{array}{l}12.32-2.38 X_{1}-1.77 X_{2}+1.31 X_{3}+1.57 X_{4}+0.33 X_{1} X_{2}- \\
0.40 X_{1} X_{3}+2.21 X_{1} X_{4}+1.37 X_{2} X_{3}-0.86 X_{2} X_{4}+0.60 X_{3} X_{4} \\
-4.35 X_{1}^{2}+0.29 X_{2}^{2}-2.25 X_{3}^{2}+0.24 X_{4}^{2}\end{array}$ & 0.8934 \\
\hline & Mandarin peel & $\begin{array}{l}16.29-1.12 X_{1}-1.06 X_{2}+2.37 X_{3}+2.49 X_{4}-1.64 X_{1} X_{2} \\
+0.45 X_{1} X_{3}+0.52 X_{1} X_{4}-2.82 X_{2} X_{3}+1.00 X_{2} X_{4}+0.46 X_{3} X_{4} \\
-2.24 X_{1}^{2}+1.12 X_{2}^{2}+3.50 X_{3}^{2}+2.33 X_{4}^{2}\end{array}$ & 0.9055 \\
\hline
\end{tabular}

Table 5. Analysis of variance test using Design-Expert 10.0.4 for the HAE of TBC in the relevant wastes.

\begin{tabular}{|c|c|c|c|c|c|c|}
\hline & Source & $\begin{array}{l}\text { Sum of } \\
\text { Squares }\end{array}$ & df & $\begin{array}{l}\text { Mean } \\
\text { Square }\end{array}$ & F Value & $\begin{array}{l}p \text {-Value } \\
\text { Prob }>\text { F }\end{array}$ \\
\hline \multirow{19}{*}{ Olive leaf } & Model & 1687.74 & 14 & 120.55 & 12.04 & $<0.0001$ \\
\hline & $X_{1}$-Solvent concentration & 291.40 & 1 & 291.40 & 29.11 & $<0.0001$ \\
\hline & $X_{2}$-Solid Mass & 112.59 & 1 & 112.59 & 11.25 & 0.0047 \\
\hline & $X_{3}$-Extraction time & 877.76 & 1 & 877.76 & 87.69 & $<0.0001$ \\
\hline & $X_{4}$-Speed & 59.43 & 1 & 59.43 & 5.94 & 0.0288 \\
\hline & $X_{1} X_{2}$ & 4.41 & 1 & 4.41 & 0.4406 & 0.5176 \\
\hline & $X_{1} X_{3}$ & 0.1111 & 1 & 0.1111 & 0.0111 & 0.9176 \\
\hline & $X_{1} X_{4}$ & 1.20 & 1 & 1.20 & 0.1198 & 0.7344 \\
\hline & $X_{2} X_{3}$ & 101.17 & 1 & 101.17 & 10.11 & 0.0067 \\
\hline & $X_{2} X_{4}$ & 22.40 & 1 & 22.40 & 2.24 & 0.1568 \\
\hline & $X_{3} X_{4}$ & 2.18 & 1 & 2.18 & 0.2177 & 0.6480 \\
\hline & $X_{1}^{2}$ & 196.74 & 1 & 196.74 & 19.65 & 0.0006 \\
\hline & $X_{2}^{2}$ & 0.8401 & 1 & 0.8401 & 0.0839 & 0.7763 \\
\hline & $X_{3}^{2}$ & 16.33 & 1 & 16.33 & 1.63 & 0.2223 \\
\hline & $X_{4}^{2}$ & 11.21 & 1 & 11.21 & 1.12 & 0.3079 \\
\hline & Residual & 140.14 & 14 & 10.01 & & \\
\hline & Lack of Fit & 135.12 & 10 & 13.51 & 10.76 & 0.0175 \\
\hline & Pure Error & 5.02 & 4 & 1.26 & & \\
\hline & Cor Total & 1827.88 & 28 & & & \\
\hline \multirow{19}{*}{ Grape fruit } & Model & 203.89 & 14 & 14.56 & 11.80 & $<0.0001$ \\
\hline & $X_{1}$ & 12.33 & 1 & 12.33 & 9.99 & 0.0069 \\
\hline & $X_{2}$ & 84.48 & 1 & 84.48 & 68.45 & $<0.0001$ \\
\hline & $X_{3}$ & 10.69 & 1 & 10.69 & 8.66 & 0.0107 \\
\hline & $X_{4}$ & 9.05 & 1 & 9.05 & 7.33 & 0.0170 \\
\hline & $X_{1} X_{2}$ & 0.4900 & 1 & 0.4900 & 0.3970 & 0.5388 \\
\hline & $X_{1} X_{3}$ & 0.4444 & 1 & 0.4444 & 0.3601 & 0.5580 \\
\hline & $X_{1} X_{4}$ & 1.10 & 1 & 1.10 & 0.8893 & 0.3617 \\
\hline & $X_{2} X_{3}$ & 0.3211 & 1 & 0.3211 & 0.2602 & 0.6179 \\
\hline & $X_{2} X_{4}$ & 27.74 & 1 & 27.74 & 22.48 & 0.0003 \\
\hline & $X_{3} X_{4}$ & 5.22 & 1 & 5.22 & 4.23 & 0.0588 \\
\hline & $X_{1}^{2}$ & 0.1735 & 1 & 0.1735 & 0.1406 & 0.7133 \\
\hline & $X_{2}^{2}$ & 25.91 & 1 & 25.91 & 20.99 & 0.0004 \\
\hline & $X_{3}^{2}$ & 8.85 & 1 & 8.85 & 7.17 & 0.0180 \\
\hline & $X_{4}^{2}$ & 10.13 & 1 & 10.13 & 8.21 & 0.0125 \\
\hline & Residual & 17.28 & 14 & 1.23 & & \\
\hline & Lack of Fit & 11.08 & 10 & 1.11 & 0.7153 & 0.6969 \\
\hline & Pure Error & 6.20 & 4 & 1.55 & & \\
\hline & Cor Total & 221.17 & 28 & & & \\
\hline
\end{tabular}


Table 5. Cont.

\begin{tabular}{|c|c|c|c|c|c|c|}
\hline & Source & $\begin{array}{l}\text { Sum of } \\
\text { Squares }\end{array}$ & df & $\begin{array}{l}\text { Mean } \\
\text { Square }\end{array}$ & F Value & $\begin{array}{l}p \text {-Value } \\
\text { Prob }>\text { F }\end{array}$ \\
\hline \multirow{19}{*}{ Lemon peel } & Model & 410.79 & 14 & 29.34 & 8.38 & 0.0001 \\
\hline & $X_{1}$ & 57.89 & 1 & 57.89 & 16.54 & 0.0012 \\
\hline & $X_{2}$ & 54.19 & 1 & 54.19 & 15.48 & 0.0015 \\
\hline & $X_{3}$ & 17.10 & 1 & 17.10 & 4.89 & 0.0442 \\
\hline & $X_{4}$ & 29.73 & 1 & 29.73 & 8.49 & 0.0113 \\
\hline & $X_{1} X_{2}$ & 0.3403 & 1 & 0.3403 & 0.0972 & 0.7598 \\
\hline & $X_{1} X_{3}$ & 0.6553 & 1 & 0.6553 & 0.1872 & 0.6718 \\
\hline & $X_{1} X_{4}$ & 36.00 & 1 & 36.00 & 10.29 & 0.0063 \\
\hline & $X_{2} X_{3}$ & 7.47 & 1 & 7.47 & 2.13 & 0.1661 \\
\hline & $X_{2} X_{4}$ & 4.35 & 1 & 4.35 & 1.24 & 0.2835 \\
\hline & $X_{3} X_{4}$ & 0.2268 & 1 & 0.2268 & 0.0648 & 0.8028 \\
\hline & $X_{1}^{2}$ & 126.78 & 1 & 126.78 & 36.22 & $<0.0001$ \\
\hline & $X_{2}^{2}$ & 15.87 & 1 & 15.87 & 4.53 & 0.0515 \\
\hline & $X_{3}^{2}$ & 27.58 & 1 & 27.58 & 7.88 & 0.0140 \\
\hline & $X_{4}^{2}$ & 6.33 & 1 & 6.33 & 1.81 & 0.1999 \\
\hline & Residual & 49.00 & 14 & 3.50 & & \\
\hline & Lack of Fit & 47.39 & 10 & 4.74 & 11.77 & 0.0148 \\
\hline & Pure Error & 1.61 & 4 & 0.4025 & & \\
\hline & Cor Total & 459.79 & 28 & & & \\
\hline \multirow{19}{*}{$\begin{array}{c}\text { Mandarin } \\
\text { peel }\end{array}$} & Model & 390.34 & 14 & 27.88 & 9.58 & $<0.0001$ \\
\hline & $X_{1}$ & 14.94 & 1 & 14.94 & 5.13 & 0.0399 \\
\hline & $X_{2}$ & 13.50 & 1 & 13.50 & 4.64 & 0.0492 \\
\hline & $X_{3}$ & 67.65 & 1 & 67.65 & 23.24 & 0.0003 \\
\hline & $X_{4}$ & 74.42 & 1 & 74.42 & 25.57 & 0.0002 \\
\hline & $X_{1} X_{2}$ & 10.80 & 1 & 10.80 & 3.71 & 0.0746 \\
\hline & $X_{1} X_{3}$ & 0.8186 & 1 & 0.8186 & 0.2812 & 0.6042 \\
\hline & $X_{1} X_{4}$ & 1.09 & 1 & 1.09 & 0.3734 & 0.5509 \\
\hline & $X_{2} X_{3}$ & 31.79 & 1 & 31.79 & 10.92 & 0.0052 \\
\hline & $X_{2} X_{4}$ & 4.00 & 1 & 4.00 & 1.37 & 0.2607 \\
\hline & $X_{3} X_{4}$ & 0.8372 & 1 & 0.8372 & 0.2876 & 0.6002 \\
\hline & $X_{1}^{2}$ & 32.63 & 1 & 32.63 & 11.21 & 0.0048 \\
\hline & $X_{2}^{2}$ & 8.20 & 1 & 8.20 & 2.82 & 0.1154 \\
\hline & $X_{3}^{2}$ & 79.47 & 1 & 79.47 & 27.30 & 0.0001 \\
\hline & $X_{4}^{2}$ & 35.33 & 1 & 35.33 & 12.14 & 0.0037 \\
\hline & Residual & 40.76 & 14 & 2.91 & & \\
\hline & Lack of Fit & 39.24 & 10 & 3.92 & 10.37 & 0.0187 \\
\hline & Pure Error & 1.51 & 4 & 0.3784 & & \\
\hline & Cor Total & 431.09 & 28 & & & \\
\hline
\end{tabular}

Another statistical parameter to determine the adequacy of the proposed models for the experimental data is the value of lack of fit. The model proposed for grapefruit peel extraction had a non-significant lack of fit value $(p>0.05)$, meaning that the model is in good agreement with the experimental output. However, the remaining models had significant values for lack of fit, showing similarity with the other reports [33-38]. Kittisuban et al. declared that lack of fit with a significant value might be acceptable if there are lots of data in the relevant process system [37].

\subsection{Effects of Independent Variables on the TBC Yields}

Solid mass had a negative effect on each system (Figures 1a-4a). This result is to be expected from a mass transfer point of view [31]. By increasing the solid mass, the liquid extract was saturated with the target components, which unfavored the rate of mass transfer by preventing the diffusion of the biophenols into the solvent [39]. On the other hand, increasing the solvent concentration in water favored the extraction at first (Figures $1 b-4 b$ ). Later, it started to decrease after the composition reached to a value of $\approx 50 \%(v / v)$. Similar observations have also been attained in other reports, where 
bioactive ingredients were extracted from several natural sources [40-42]. A decrease in the amount of ethanol amount in water might be hypothesized by the denaturation property of the ethanol [32]. Regarding extraction time, there was a markable increase in each system (Figures $1 \mathrm{~b}-4 \mathrm{~b}$ ). Zhong and Wang [43], Silva et al. [44] and Ramić et al. [45] also had observed similar results for the time effect on the extraction of various natural products. Mixing speed had a slight effect on both olive leaf and lemon peel extraction (Figures $1 \mathrm{c}$ and $3 \mathrm{c}$ ). As for grapefruit peel and mandarin peel extractions, speed of the homogenizer decreased the TBC yields up to a certain value, at which point the yield began to rise. This might be attributable to the initial degradation of the biophenol-degrading enzymes, which in turn caused these bioactive substances to precipitate [46].
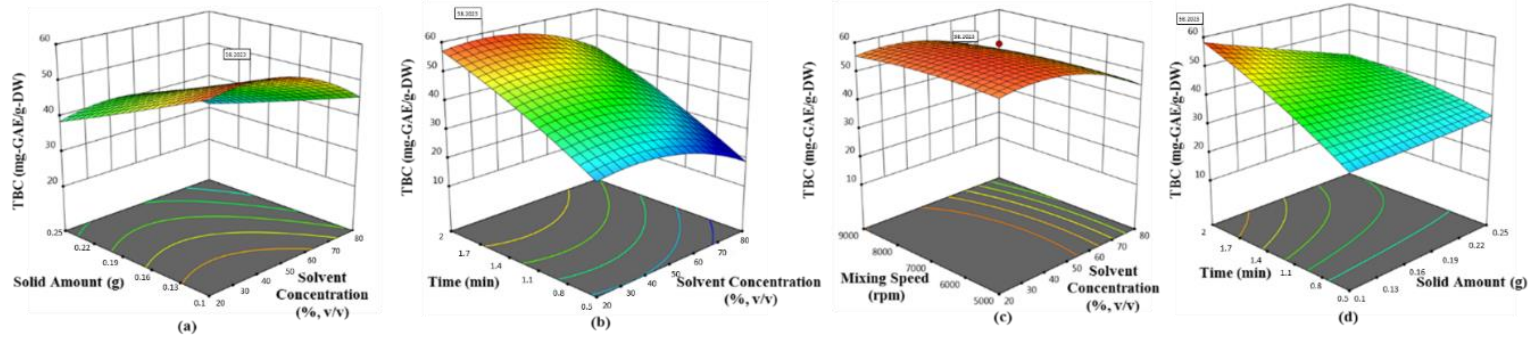

Figure 1. Response surface plot for the TBC of olive leaf extract (a) as a function of solvent concentration to solid mass (extraction time $=2 \mathrm{~min}$ and mixing speed $=6517.41 \mathrm{rpm}$ ); (b) as a function of solvent concentration to time (solid mass $=0.1 \mathrm{~g}$ and mixing speed $=6517.41 \mathrm{rpm}$ ); (c) as a function of solvent concentration to mixing speed (solid mass $=0.1 \mathrm{~g}$ and extraction time $=2 \mathrm{~min}$ ); (d) as a function of solid mass to extraction time (solvent concentration $=34.31$ and mixing speed $=6517.41 \mathrm{rpm}$ ).
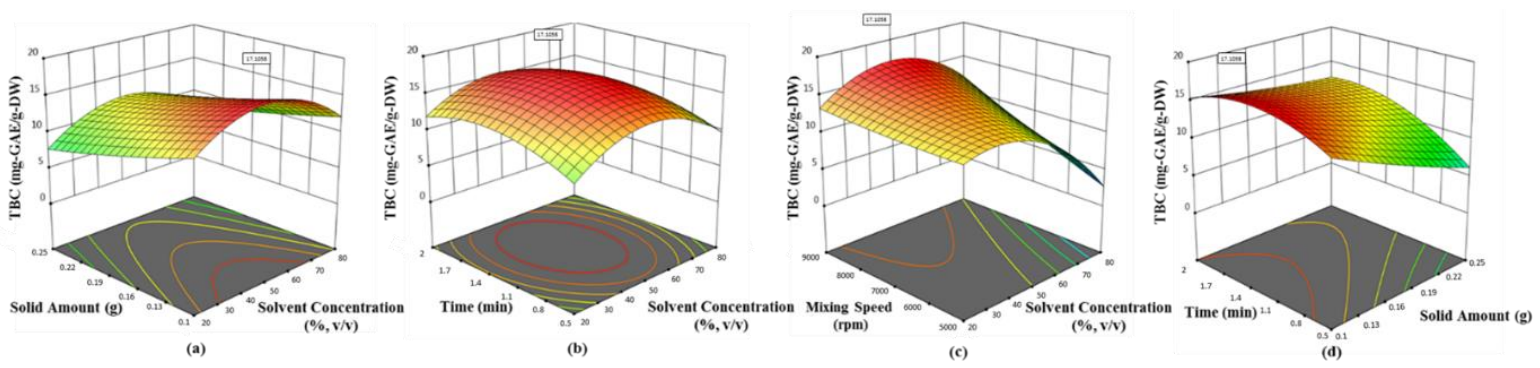

Figure 2. Response surface plot for the TBC of grapefruit peel extract (a) as a function of solvent concentration to solid mass (extraction time $=1.125 \mathrm{~min}$ and mixing speed $=5000 \mathrm{rpm}$ ); (b) as a function of solvent concentration to time (solid mass $=0.1 \mathrm{~g}$ and mixing speed $=5000 \mathrm{rpm}$ ); (c) as a function of solvent concentration to mixing speed (solid mass $=0.1 \mathrm{~g}$ and extraction time $=1.125 \mathrm{~min}$ ); (d) as a function of solid mass to extraction time (solvent concentration $=42.32$ and mixing speed $=5000 \mathrm{rpm}$ ).
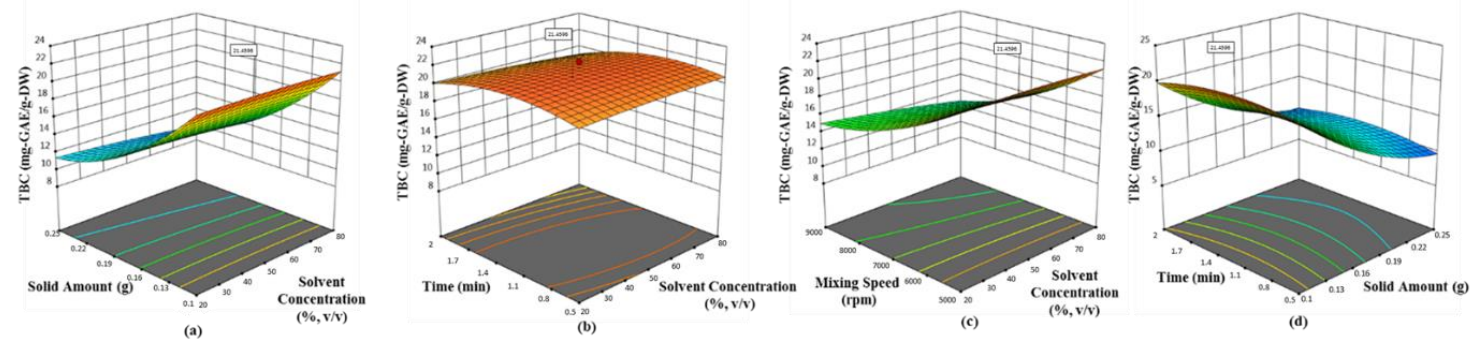

Figure 3. Response surface plot for the TBC of lemon peel extract (a) as a function of solvent concentration to solid mass (extraction time $=1.34 \mathrm{~min}$ and mixing speed $=8999.99 \mathrm{rpm}$ ); $(\mathbf{b})$ as a function of solvent concentration to time (solid mass $=0.1 \mathrm{~g}$ and mixing speed $=8999.99 \mathrm{rpm}$ ); (c) as a function of solvent concentration to mixing speed (solid mass $=0.1 \mathrm{~g}$ and extraction time $=1.34 \mathrm{~min}$ ); (d) as a function of solid mass to extraction time (solvent concentration $=48.09$ and mixing speed $=$ $8999.99 \mathrm{rpm})$. 

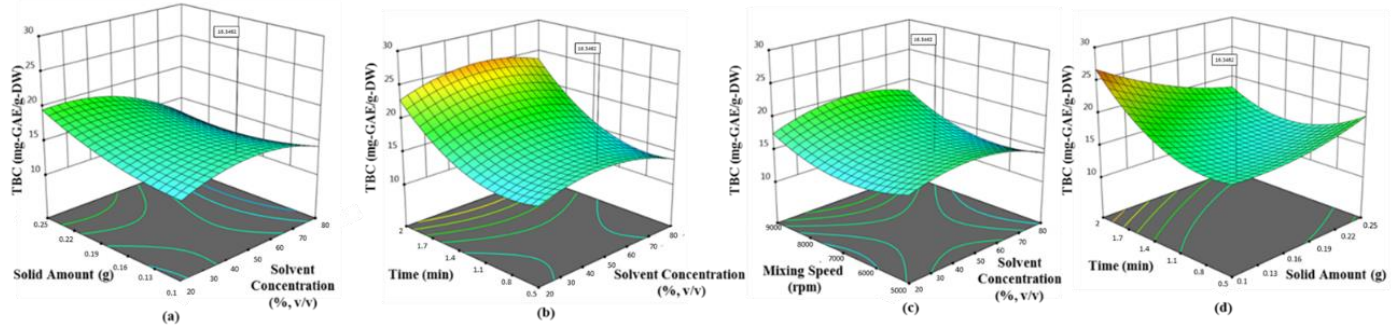

Figure 4. Response surface plot for the TBC of mandarin peel extract (a) as a function of solvent concentration to solid mass (extraction time $=0.70 \mathrm{~min}$ and mixing speed $=6372.15 \mathrm{rpm}$ ); $(\mathbf{b})$ as a function of solvent concentration to time (solid mass $=0.154 \mathrm{~g}$ and mixing speed $=6372.15 \mathrm{rpm}$ ); (c) as a function of solvent concentration to mixing speed (solid mass $=0.154 \mathrm{~g}$ and extraction time $=$ $0.70 \mathrm{~min}$ ); (d) as a function of solid mass to extraction time (solvent concentration $=30.80$ and mixing speed $=6372.15 \mathrm{rpm})$

\subsection{Verification of the Suggested Conditions}

Table 6 summarizes the optimum HAE conditions for TBC from each residue to achieve the greatest yield with the verification results. The second-order polynomial models proposed for the relevant systems have been confirmed to be satisfactory to estimate the suggested conditions depending on the small and acceptable levels of error rate (\%).

Table 6. Verification results of the optimum conditions for the HAE of each residue.

\begin{tabular}{|c|c|c|c|c|c|}
\hline \multirow{3}{*}{ Item } & \multirow{3}{*}{\multicolumn{2}{|c|}{ Optimum Extraction Conditions }} & \multirow{2}{*}{\multicolumn{3}{|c|}{$\begin{array}{c}\text { Maximum } \\
\text { TBC (mg-GAE/g-DW) }\end{array}$}} \\
\hline & & & & & \\
\hline & & & Experimental & Predicted & Error\% \\
\hline \multirow{4}{*}{ Olive leaf } & $X_{1}(\% . v / v)$ & 34.24 & \multirow{4}{*}{58.62} & \multirow{4}{*}{59.16} & \multirow{4}{*}{0.92} \\
\hline & $X_{2}(\mathrm{~g})$ & 0.100 & & & \\
\hline & $X_{3}(\min )$ & 2.00 & & & \\
\hline & $X_{4}(\mathrm{rpm})$ & 6522.2 & & & \\
\hline \multirow{4}{*}{ Grapefruit peel } & $X_{1}$ & 42.33 & \multirow{4}{*}{21.12} & \multirow{4}{*}{21.46} & \multirow{4}{*}{1.61} \\
\hline & $X_{2}$ & 0.100 & & & \\
\hline & $X_{3}$ & 1.125 & & & \\
\hline & $X_{4}$ & 5000 & & & \\
\hline \multirow{4}{*}{ Lemon peel } & $X_{1}$ & 33.62 & \multirow{4}{*}{16.89} & \multirow{4}{*}{17.07} & \multirow{4}{*}{1.07} \\
\hline & $X_{2}$ & 0.100 & & & \\
\hline & $X_{3}$ & 1.282 & & & \\
\hline & $X_{4}$ & 5007 & & & \\
\hline \multirow{4}{*}{ Mandarin peel } & $X_{1}$ & 42.5 & \multirow{4}{*}{27.79} & \multirow{4}{*}{28.94} & \multirow{4}{*}{4.14} \\
\hline & $X_{2}$ & 0.100 & & & \\
\hline & $X_{3}$ & 1.99 & & & \\
\hline & $X_{4}$ & 8772 & & & \\
\hline
\end{tabular}

\subsection{Evaluation of the Bioactive Ingredients in the Extracts}

Table 7 demonstrates the quantitative results of the most prominent phenolic compounds of each item. When the spectrophotometric analysis is assessed (Table 8), the related biophenols have proven to be the most contributing compounds to bioactive properties. A mathematical statement can be formed to confirm the concerned relationship by means of correlation coefficients between the relevant dependent variables (oleuropein/naringin and TBC; oleuropein/naringin and DPPH/CUPRAC/ABTS; TBC and DPPH/CUPRAC/ABTS). When the coefficients of correlation (0.8517) are checked, a strong relationship between the individual and total biophenols is observed. Furthermore, the relationships $(>0.94)$ between the total biophenols and each antioxidant activity assay finding are also extremely 
satisfactory for verifying the contribution of total biophenols to the antioxidant capacity of the selected waste products.

Table 7. Major bioactive compounds derived from the selected byproducts under optimal extraction conditions*.

\begin{tabular}{cccc}
\hline Item & $\mathbf{R}_{\mathbf{t}}(\mathbf{m i n})$ & Major Biophenols & Concentration $(\mathbf{m g} / \mathbf{g}-\mathbf{D W})$ \\
\hline Olive leaf & 5.910 & Oleuropein & $79.26 \pm 0.001^{\mathrm{a}}$ \\
\hline Grapefruit peel & 5.400 & Naringin & $36.10 \pm 0.001^{\mathrm{b}}$ \\
\hline Lemon peel & 5.400 & Naringin & $10.33 \pm 0.002^{\mathrm{c}}$ \\
\hline Mandarin peel & 5.400 & Naringin & $25.56 \pm 0.001^{\mathrm{d}}$
\end{tabular}

* Data are given as the mean $(n=3) \pm$ standard deviation. Lines not sharing a common $(a, b, c$ and $d)$ letter indicate significant differences at $p<0.001$.

Table 8. Antioxidant properties of the relevant residues *.

\begin{tabular}{|c|c|c|c|c|}
\hline Item. & $\begin{array}{c}\text { ТВC } \\
\text { (mg-GAE/g-DW) }\end{array}$ & $\begin{array}{c}\text { DPPH } \\
\text { (mg-TAEC/g-DW) }\end{array}$ & $\begin{array}{c}\text { CUPRAC } \\
\text { (mg-TAEC/g-DW) }\end{array}$ & $\begin{array}{c}\text { ABTS } \\
(\mathrm{mg}-\mathrm{TAEC} / \mathrm{g}-\mathrm{DW})\end{array}$ \\
\hline Olive leaf & $16.86 \pm 0.004^{\mathrm{a}}$ & $20.39 \pm 0.001^{\mathrm{a}}$ & $64.01 \pm 0.003^{\mathrm{a}}$ & $60.12 \pm 0.001^{a}$ \\
\hline Grapefruit peel & $5.39 \pm 0.002^{b}$ & $1.78 \pm 0.001^{\mathrm{b}}$ & $20.61 \pm 0.001^{b}$ & $555.02 \pm 0.002^{b}$ \\
\hline Lemon peel & $3.44 \pm 0.001^{c}$ & $2.36 \pm 0.001^{\mathrm{c}}$ & $24.05 \pm 0.002^{c}$ & $69.71 \pm 0.002^{c}$ \\
\hline Mandarin peel & $8.96 \pm 0.003^{d}$ & $5.58 \pm 0.002^{d}$ & $32.34 \pm 0.003^{d}$ & $326.76 \pm 0.004^{d}$ \\
\hline
\end{tabular}

${ }^{*}$ Data are given as the mean $(n=3) \pm$ standard deviation. Lines not sharing a common letter $(a, b, c$ and $d)$ indicate significant differences at $p<0.001$.

On the other hand, selected antioxidant activity methods also showed positive correlations with each other. The correlation coefficients between DPPH and CUPRAC, CUPRAC and ABTS, and DPPH and ABTS were found as $0.9955,0.9052$ and 0.8764 , respectively.

\subsection{Infrared Spectra of the Extracts}

A large variety of samples such as powders, films, liquids and solids can be studied using this characterization technique which clarifies the functional groups in the samples studied. Figure 5 demonstrates the FTIR spectra of the selected waste extracts obtained at optimum conditions, which comprises the range between 4000 and $500 \mathrm{~cm}^{-1}$. The peaks ranging from 3010 to $3670 \mathrm{~cm}^{-1}$ correspond to the $\mathrm{O}-\mathrm{H}$ stretch of the hydroxyl group, comprising biophenols and alcohols [47]. The sharper peaks observed between 3409 and $1733 \mathrm{~cm}^{-1}$ are assigned to $\mathrm{C}=\mathrm{O}$ and $\mathrm{O}-\mathrm{H}$ stretchings, which are attributable to oleuropein, naringin and other phenolic compounds of the leaf and peel extracts [48]. The band located at $500-800 \mathrm{~cm}^{-1}$ characterizes $\mathrm{C}-\mathrm{H}$, denoting the alkanes and aromatics [49].

\subsection{Nanostructural Morphologies of the Extracts}

AFM is a suitable technique to explore the parameters of average surface roughness, homogeneity and particle size distribution for biomaterials with high resolution topographic images [50]. Evaluation of the interfacial behavior of the surface is crucial to understanding the interactions of the selected systems. In this regard, AFM was conducted to realize the morphological and nanostructure changes of the extracted materials. This technique provided a visualization of the deposited materials with a nanometric resolution. Figure 6a,b demonstrates two-dimensional (2D) AFM images of the olive leaf samples obtained before and after the extraction processes, respectively. From the 2D images, cross-section profiles and histograms, it is revealed that untreated leaves have more grains and particles when compared to those of treated samples. The significant difference observed between these two structures is due to the extraction process. As can be seen in Figure 6a, the heterogeneously distributed particles of various sizes cover all of the surfaces. The chemical composition of the olive leaves, 
consisting of the minerals, chlorophylls, fatty acids and phenolic substances, are removed after the extraction process. The histogram plots clarified that the average size distribution was about $750 \mathrm{~nm}$ for the untreated samples, while it was nearly $250 \mathrm{~nm}$ for the treated leaves.

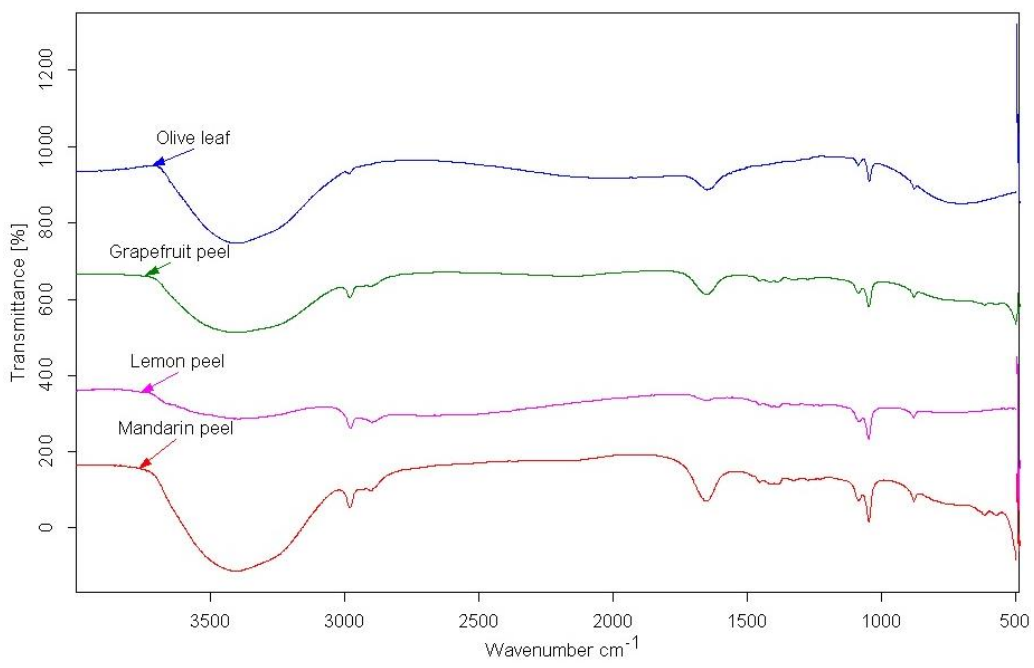

Figure 5. FTIR spectra of the relevant residues.
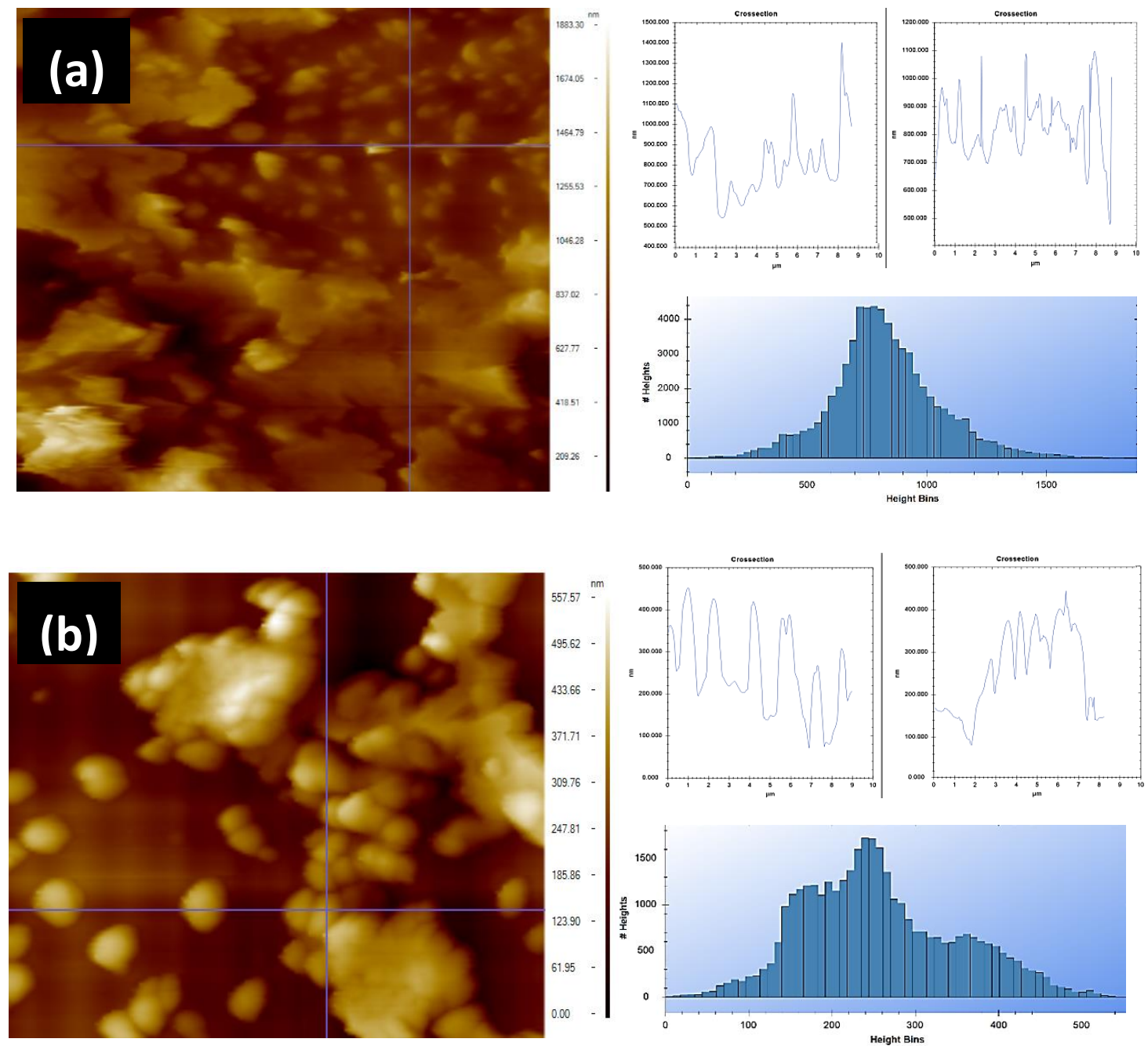

Figure 6. 2D AFM- atomic force microscopy images, cross-section profiles and histograms of the olive leaf samples (a) before and (b) after extraction. 
Figure $7 \mathrm{a}, \mathrm{b}$ represents the lemon peel before and after extraction processes. It is noteworthy that the lemon peel had a spikier structure after the extraction process compared with the randomly distributed particles shown in Figure 7a. The spaces and the valleys in the sample obtained after the extraction process were higher than the untreated lemon peels. According to the histogram plots, the average heights of the particles are different, while their size distributions are nearly the same. After the extraction process, compact, spiky and porous structures were observed, indicating some biophenolic substances were removed from the peel matrix.
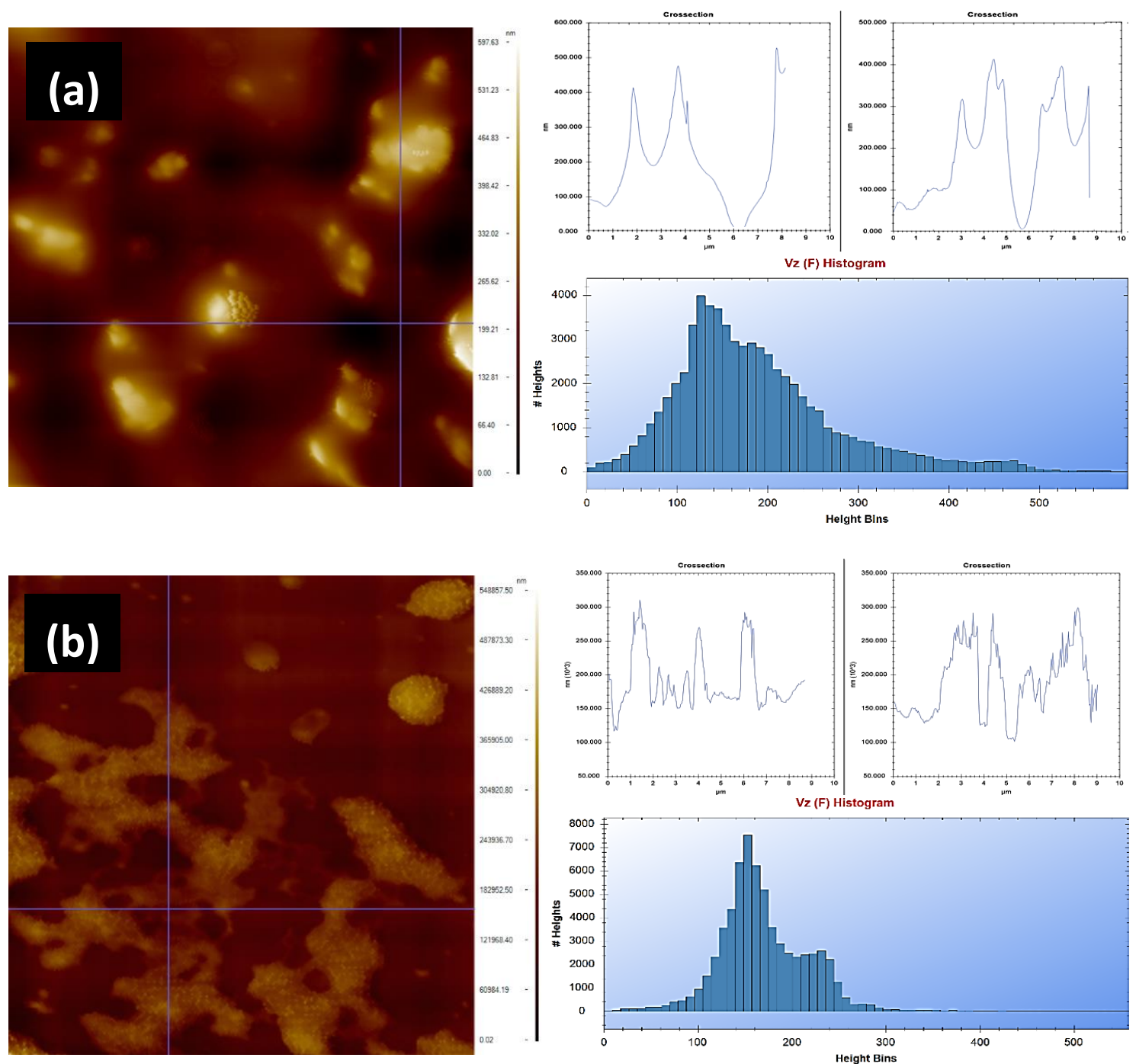

Figure 7. 2D AFM images, cross-section profiles and histograms of the lemon peel samples (a) before and $(\mathbf{b})$ after extraction.

\section{Conclusions}

Olive leaf was found to possess the highest phenolic ingredients $(58.62 \mathrm{mg}-\mathrm{GAE} / \mathrm{g}-\mathrm{DW}$ with $0.1 \mathrm{~g}$ sample, $42.5 \%$ ethanol at $6522.2 \mathrm{rpm}$ for $2 \mathrm{~min}$ ), followed by mandarin peel ( $27.79 \mathrm{mg}-\mathrm{GAE} / \mathrm{g}-\mathrm{DW}$ with $0.1 \mathrm{~g}$ sample, $34.24 \%$ ethanol at $8772 \mathrm{rpm}$ for $1.99 \mathrm{~min}$ ), grapefruit peel (21.12 mg-GAE/g-DW with $0.1 \mathrm{~g}$ sample, $42.33 \%$ ethanol at $5000 \mathrm{rpm}$ for $1.125 \mathrm{~min}$ ) and lemon peel (16.89 mg-GAE/g-DW with $0.1 \mathrm{~g}$ sample, $33.62 \%$ ethanol at $5007 \mathrm{rpm}$ for $1.282 \mathrm{~min}$ ). The quadratic models proposed by Box-Behnken design were found satisfactory, depending on the statistical results $(p<0.0001$ and $R^{2}>0.89$ ). The convincing correlation coefficients $(>0.94)$ between the phenolic ingredients and antioxidant activity tested by each assay proved that polyphenols in the selected waste products 
were the most contributing substances of bioactive properties. Hereby, the present findings will be guidance for science researchers, consumers and commercial entities (cosmetic, pharmaceutical and food industries) with a green process developed for the extraction of the most popular Mediterranean crops. On the other hand, additional studies are necessary to determine whether there is a link between possible prominent compounds in the extracts related to health benefits. In short, the need for newly developed natural additives is very clear, but the most important issue is to be careful that the product is reliable.

Author Contributions: Conceptualization, S.S.; Data curation, E.K.; Methodology, S.S.; Software, E.K.; Supervision, S.S.; Validation, E.K.; Visualization, S.Y.; Writing—original draft, S.S.; Writing—review \& editing, D.M. and S.S.

Funding: This research received no external funding.

Conflicts of Interest: The authors declare that there is no conflict of interest in writing upon submission of the manuscript.

\section{References}

1. Mirabella, N.; Castellani, V.; Sala, S. Current options for the valorization of food manufacturing waste: A review. J. Clean. Prod. 2014, 65, 28-41. [CrossRef]

2. Galanakis, C.M. Recovery of high added-value components from food wastes: Conventional, emerging technologies and commercialized applications. Trends Food Sci. Technol. 2012, 26, 68-87. [CrossRef]

3. Masmoudi, M.; Besbes, S.; Chaabouni, M.; Robert, C.; Paquot, M.; Blecker, C.; Attia, H. Optimization of pectin extraction from lemon by-product with acidified date juice using response surface methodology. Carbohydr. Polym. 2008, 74, 185-192. [CrossRef]

4. Kim, W.C.; Lee, D.Y.; Lee, C.H.; Kim, C.W. Optimization of narirutin extraction during washing step of the pectin production from citrus peels. J. Food Eng. 2004, 63, 191-197. [CrossRef]

5. Lagha-Benamrouche, S.; Madani, K. Phenolic contents and antioxidant activity of orange varieties (Citrus sinensis L. and Citrus aurantium L.) cultivated in Algeria: Peels and leaves. Ind. Crops Prod. 2013, 50, 723-730. [CrossRef]

6. Karsheva, M.; Alexandrova, S.; Karsheva, M.; Kirova, E.; Alexandrova, S. Natural antioxidants from citrus mandarin peels. Extraction of polyphenols; effect of operational conditions on total polyphenols contents and antioxidant activity. J. Chem. Technol. Metall. 2013, 48, 35-41.

7. Wang, W.; Ma, X.; Xu, Y.; Cao, Y.; Jiang, Z.; Ding, T.; Ye, X.; Liu, D. Ultrasound-assisted heating extraction of pectin from grapefruit peel: Optimization and comparison with the conventional method. Food Chem. 2015, 178, 106-114. [CrossRef]

8. Chedea, V.S.; Kefalas, P.; Socaciu, C. Patterns of Carotenoid Pigments Extracted from Two Orange Peel Wastes (Valencia and Navel Var.). J. Food Biochem. 2010, 34, 101-110. [CrossRef]

9. Farhat, A.; Fabiano-Tixier, A.-S.; Maataoui, M.E.; Maingonnat, J.-F.; Romdhane, M.; Chemat, F. Microwave steam diffusion for extraction of essential oil from orange peel: Kinetic data, extract's global yield and mechanism. Food Chem. 2011. [CrossRef]

10. Singanusong, R.; Nipornram, S.; Tochampa, W.; Rattanatraiwong, P. Low Power Ultrasound-Assisted Extraction of Phenolic Compounds from Mandarin (Citrus reticulata Blanco cv. Sainampueng) and Lime (Citrus aurantifolia) Peels and the Antioxidant. Food Anal. Methods 2015, 8, 1112-1123. [CrossRef]

11. Ateş, F.; Şahin, S.; İlbay, Z.; Kırbaşlar, Ş.İ. A Green Valorisation Approach Using Microwaves and Supercritical $\mathrm{CO} 2$ for High-Added Value Ingredients from Mandarin (Citrus deliciosa Tenore) Leaf Waste. Waste Biomass Valorization 2017, 1-14. [CrossRef]

12. Li, B.B.; Smith, B.; Hossain, M.M. Extraction of phenolics from citrus peels: II. Enzyme-assisted extraction method. Sep. Purif. Technol. 2006, 48, 189-196. [CrossRef]

13. Guimarães, R.; Barros, L.; Barreira, J.C.M.; Sousa, M.J; Carvalho, A.M.; Ferreira, I.C.F.R. Targeting excessive free radicals with peels and juices of citrus fruits: Grapefruit, lemon, lime and orange. Food Chem. Toxicol. 2010, 48, 99-106. [CrossRef] [PubMed]

14. Pereira, A.P.; Ferreira, I.C.; Marcelino, F.; Valentão, P.; Andrade, P.B.; Seabra, R.; Estevinho, L.; Bento, A.; Pereira, J.A. Phenolic Compounds and Antimicrobial Activity of Olive (Olea europaea L. Cv. Cobrançosa) Leaves. Molecules 2007, 12, 1153-1162. [CrossRef] [PubMed] 
15. Şahin, S.; Bilgin, M. Olive tree (Olea europaea L.) leaf as a waste by-product of table olive and olive oil industry: A review. J. Sci. Food Agric. 2017. [CrossRef]

16. Souilem, S.; Fki, I.; Kobayashi, I.; Khalid, N.; Neves, M.A.; Isoda, H.; Sayadi, S.; Nakajima, M. Emerging Technologies for Recovery of Value-Added Components from Olive Leaves and Their Applications in Food/Feed Industries. Food Bioprocess Technol. 2017, 10, 229-248. [CrossRef]

17. Şahin, S.; İlbay, Z.; Kırbaşlar, Ş.İ. Study on Optimum Extraction Conditions for Olive Leaf Extracts Rich in Polyphenol and Flavonoid. Sep. Sci. Technol. 2015, 50, 1181-1189. [CrossRef]

18. Xynos, N.; Papaefstathiou, G.; Gikas, E.; Argyropoulou, A.; Aligiannis, N.; Skaltsounis, A.-L. Design optimization study of the extraction of olive leaves performed with pressurized liquid extraction using response surface methodology. Sep. Purif. Technol. 2014, 122, 323-330. [CrossRef]

19. Putnik, P.; Barba, F.J.; Španić, I.; Zorić, Z.; Dragović-Uzelac, V.; Bursać Kovačević, D. Green extraction approach for the recovery of polyphenols from Croatian olive leaves (Olea europea). Food Bioprod. Process. 2017, 106, 19-28. [CrossRef]

20. Sahin, S.; Samli, R.; Birteks Z Tan, A.S.; Barba, F.J.; Chemat, F.; Cravotto, G.; Lorenzo, J.M. Solvent-free microwave-assisted extraction of polyphenols from olive tree leaves: Antioxidant and antimicrobial properties. Molecules 2017, 22. [CrossRef]

21. Mourtzinos, I.; Anastasopoulou, E.; Petrou, A.; Grigorakis, S.; Makris, D.; Biliaderis, C.G. Optimization of a green extraction method for the recovery of polyphenols from olive leaf using cyclodextrins and glycerin as co-solvents. J. Food Sci. Technol. 2016, 53, 3939-3947. [CrossRef] [PubMed]

22. Athanasiadis, V.; Grigorakis, S.; Lalas, S.; Makris, D.P. Highly Efficient Extraction of Antioxidant Polyphenols from Olea europaea Leaves Using an Eco-friendly Glycerol/Glycine Deep Eutectic Solvent. Waste Biomass Valorization 2017, 1-8. [CrossRef]

23. Khemakhem, I.; Gargouri, O.D.; Dhouib, A.; Ayadi, M.A.; Bouaziz, M. Oleuropein rich extract from olive leaves by combining microfiltration, ultrafiltration and nanofiltration. Sep. Purif. Technol. 2017, 172, 310-317. [CrossRef]

24. Malik, N.S.A.; Bradford, J.M. Changes in oleuropein levels during differentiation and development of floral buds in "Arbequina" olives. Sci. Hortic. 2006, 110, 274-278. [CrossRef]

25. Re, R.; Pellegrini, N.; Proteggente, A.; Pannala, A.; Yang, M.; Rice-Evans, C. Antioxidant activity applying an improved ABTS radical cation decolorization assay. Free Radic. Biol. Med. 1999, 26, 1231-1237. [CrossRef]

26. Yu, J.; Wang, L.; Walzem, R.L.; Miller, E.G.; Pike, L.M.; Patil, B.S. Antioxidant Activity of Citrus Limonoids, Flavonoids, and Coumarins. J. Agric. Food Chem. 2005, 53, 6. [CrossRef] [PubMed]

27. Şahin, S.; Şamli, R. Optimization of olive leaf extract obtained by ultrasound-assisted extraction with response surface methodology. Ultrason. Sonochem. 2013, 20, 595-602. [CrossRef] [PubMed]

28. Apak, R.; Güçlü, K.; Özyürek, M.; Çelik, S.E. Mechanism of antioxidant capacity assays and the CUPRAC (cupric ion reducing antioxidant capacity) assay. Microchim. Acta 2008, 160, 413-419. [CrossRef]

29. Bezerra, M.A.; Santelli, R.E.; Oliveira, E.P.; Villar, L.S.; Escaleira, L.A. Response surface methodology (RSM) as a tool for optimization in analytical chemistry. Talanta 2008, 76, 965-977. [CrossRef]

30. Chen, F.; Sun, Y.; Zhao, G.; Liao, X.; Hu, X.; Wu, J.; Wang, Z. Optimization of ultrasound-assisted extraction of anthocyanins in red raspberries and identification of anthocyanins in extract using high-performance liquid chromatography-mass spectrometry. Ultrason. Sonochem. 2007, 14, 767-778. [CrossRef]

31. Jeganathan, P.M.; Venkatachalam, S.; Karichappan, T.; Ramasamy, S. Model Development and Process Optimization for Solvent Extraction of Polyphenols from Red Grapes Using Box-Behnken Design. Prep. Biochem. Biotechnol. 2014, 44, 56-67. [CrossRef] [PubMed]

32. Bilgin, M.; Elhussein, E.A.A.; Özyürek, M.; Güçlü, K.; Şahin, S. Optimizing the extraction of polyphenols from Sideritis montana L. using response surface methodology. J. Pharm. Biomed. Anal. 2018, 158, 137-143. [CrossRef] [PubMed]

33. Şahin, S.; Sayim, E.; Samli, R. Comparative study of modeling the stability improvement of sunflower oil with olive leaf extract. Korean J. Chem. Eng. 2017, 34. [CrossRef]

34. Saldaña-Robles, A.; Guerra-Sánchez, R.; Maldonado-Rubio, M.I.; Peralta-Hernández, J.M. Optimization of the operating parameters using RSM for the Fenton oxidation process and adsorption on vegetal carbon of MO solutions. J. Ind. Eng. Chem. 2014, 20, 848-857. [CrossRef]

35. Şahin, S.; Sayım, E.; Bilgin, M. Effect of olive leaf extract rich in oleuropein on the quality of virgin olive oil. J. Food Sci. Technol. 2017, 54, 1721-1728. [CrossRef] 
36. Danish, M.; Hashim, R.; Ibrahim, M.N.M.; Sulaiman, O. Optimized preparation for large surface area activated carbon from date (Phoenix dactylifera L.) stone biomass. Biomass Bioenergy 2014, 61, 167-178. [CrossRef]

37. Kittisuban, P.; Ritthiruangdej, P.; Suphantharika, M. Optimization of hydroxypropylmethylcellulose, yeast $\beta$-glucan, and whey protein levels based on physical properties of gluten-free rice bread using response surface methodology. LWT-Food Sci. Technol. 2014, 57, 738-748. [CrossRef]

38. Elsen, S.R.; Ramesh, T. Optimization to develop multiple response hardness and compressive strength of zirconia reinforced alumina by using RSM and GRA. Int. J. Refract. Met. Hard Mater. 2015, 52, 159-164. [CrossRef]

39. Shouqin, Z.; Ruizhan, C.; Changzheng, W. Experiment study on ultrahigh pressure extraction of Ginsenosides. J. Food Eng. 2007, 79, 1-5. [CrossRef]

40. Liyana-Pathirana, C.; Shahidi, F. Optimization of extraction of phenolic compounds from wheat using response surface methodology. Food Chem. 2005, 93, 47-56. [CrossRef]

41. Wang, J.; Sun, B.; Cao, Y.; Tian, Y.; Li, X. Optimisation of ultrasound-assisted extraction of phenolic compounds from wheat bran. Food Chem. 2008, 106, 804-810. [CrossRef]

42. Yang, L.; Jiang, J.-G.; Li, W.-F.; Chen, J.; Wang, D.-Y.; Zhu, L. Optimum extraction Process of polyphenols from the bark of Phyllanthus emblica L. based on the response surface methodology. J. Sep. Sci. 2009, 32, 1437-1444. [CrossRef] [PubMed]

43. Zhong, K.; Wang, Q. Optimization of ultrasonic extraction of polysaccharides from dried longan pulp using response surface methodology. Carbohydr. Polym. 2010, 80, 19-25. [CrossRef]

44. Silva, E.M.; Rogez, H.; Larondelle, Y. Optimization of extraction of phenolics from Inga edulis leaves using response surface methodology. Sep. Purif. Technol. 2007, 55, 381-387. [CrossRef]

45. Ramić, M.; Vidović, S.; Zeković, Z.; Vladić, J.; Cvejin, A.; Pavlić, B. Modeling and optimization of ultrasound-assisted extraction of polyphenolic compounds from Aronia melanocarpa by-products from filter-tea factory. Ultrason. Sonochem. 2015, 23, 360-368. [CrossRef] [PubMed]

46. Hata, S. Effect of drying temperature on the oleuropein content of olive (Olea europea L.) leaves. Food Preserv. Sci. 2004, 30, 191-193. [CrossRef]

47. Khatib, A.; Perumal, V.; Ahmed, Q.U.; Uzir, B.F.; Abas, F.; Murugesu, S. Characterization of Antioxidant Activity of Momordica Charantia Fruit by Infrared-Based Fingerprinting. Anal. Lett. 2017, 50, 1977-1991. [CrossRef]

48. Khalil, M.M.H.; Ismail, E.H.; El-Baghdady, K.Z.; Mohamed, D. Green synthesis of silver nanoparticles using olive leaf extract and its antibacterial activity. Arab. J. Chem. 2014, 7, 1131-1139. [CrossRef]

49. Pavia, D.L.; Lampman, G.M.; Kriz, G.S.; Vyvyan, J.A. Introduction to Spectroscopy. Available online: https://books.google.com.tr/books?hl=tr\&lr=\&id=BuMbCgAAQBAJ\&oi=fnd\&pg=PP1\&dq=Pavia, + D., + G.+Lampman, +G.+Kriz,+and+J.+Vyvyan.+2014.+Introduction+to+spectroscopy.+5th+ed.+Stamford, +USA:+Cengage+Learning\&ots=vScRf9hY_-\&sig=KU8OCgJyyzKE8nENkiUhhEin_F8\&redir_es (accessed on 27 June 2018).

50. Ortaboy, S.; Atun, G. The electrochemical behavior of Co(TPTZ) 2 complex on different carbon based electrodes modified with TiO2 nanoparticles. Mater. Chem. Phys. 2015, 156, 129-140. [CrossRef]

(C) 2019 by the authors. Licensee MDPI, Basel, Switzerland. This article is an open access article distributed under the terms and conditions of the Creative Commons Attribution (CC BY) license (http://creativecommons.org/licenses/by/4.0/). 